\title{
The effect of drying temperature on cup quality of coffee subjected to mechanical drying
}

\author{
T.N. Sandeep*, B.B. Channabasamma, T.N. Gopinandhan and J.S. Nagaraja \\ Central Coffee Research Institute, Coffee Research Station, Chikkamagaluru -577 117, Karnataka, India
}

(Manuscript Received: 30-07-2020, Revised: 03-02-2021, Accepted: 25-02-2021)

\begin{abstract}
The objective of the work was to study the effect of drying temperature on cup quality of the robusta coffee subjected to mechanical drying in comparison with conventional sun drying. The robusta coffee processed by wet (parchment coffee) and dry (cherry coffee) methods were subjected to drying at different temperature regimes $\left(40^{\circ} \mathrm{C}, 50^{\circ} \mathrm{C}\right.$ and $\left.60^{\circ} \mathrm{C}\right)$ in a rotary mechanical dryer. The results of the study indicated that as the drying temperature increased, the time of drying reduced. Sun drying of parchment coffee took 48 hours (approximately seven days) to attain the desired moisture content of 11-12 per cent, while mechanical drying reduced the drying time to 16 to 24 hours. Similarly, cherry coffee subjected to sun drying took 88 hours (approximately 15 days), while mechanical drying reduced the drying time to 32 to 48 hours. The cup quality rating of coffee dried by different drying methods revealed that sun-dried robusta parchment coffee scored the highest cup rating. As the drying temperature increased, the cup quality ratings decreased. A similar cup quality rating was also observed with cherry coffee. These results indicate a considerable reduction of drying time when coffee beans are dried in a mechanical dryer. However, there is a need to regulate the drying temperature, which otherwise would negatively impact the quality of coffee. The drying temperature should not exceed $40{ }^{\circ} \mathrm{C}$ for preserving the innate quality of robusta coffee because the high drying rates provoked by high temperatures can cause damage to the coffee quality due to the damage caused to the cell membranes. Overall, mechanical drying is more advantageous to sun drying in-terms of drying hours (indirectly reduces dependency on manpower) and preservation of innate quality of the coffee.
\end{abstract}

Keywords: Coffee, mechanical drying, quality evaluation, robusta

\section{Introduction}

Coffee is one of the most popular beverages consumed throughout the world. Arabica and robusta are the two types of coffee normally cultivated worldwide on a commercial basis. Arabica comes up well at higher elevation where cool-climate prevails during most of the year. In comparison, robusta comes up well at a lower elevation where hot and humid climate prevails. Arabica coffee is susceptible to many pest and diseases, while robusta is resistant to many pest and diseases affecting coffee. The quality of arabica is superior compared to robusta and fetches a higher price than robusta. Coffee growing areas in India can be classified as traditional coffee-growing areas mostly consisting of Western Ghats of Karnataka, Kerala and Tamil Nadu, the non-traditional area consisting of Andhra Pradesh and Orissa and the North Eastern region consisting of all the northeastern states. The total area under coffee is about 4.59 lakh ha with a production of about $3,19,500 \mathrm{MT}$; about 30 per cent of the production is Arabica coffee. Among different states, Karnataka produces about 68 per cent, followed by Kerala (22\%), Tamil Nadu (5.5\%), Andhra Pradesh and Orissa $(3.5 \%)$ and the North-Eastern region (Database on coffee, 2020).

Coffee after harvesting at the estate is processed by two methods viz., wet and dry method. Coffee processed by wet method is known as parchment coffee, and coffee processed by the dry method is known as cherry coffees. In the dry method, after harvest, coffee fruits are spread out on a clean cemented or tiled drying yard and dried for about

*Corresponding Author:sandeepnvy@gmail.com 
12 to 15 days to bring down the safe moisture level of 11-12 per cent. Coffee obtained by dry processing is called cherry coffee. In the wet method, the harvested coffee cherries undergo a series of processing steps viz, pulping (removes the outer skin of the fruit) followed by fermentation and washing (to removes the pectinaceous mucilage adhering to the coffee bean), and sun drying for about 6 to 8 days. The coffee resulting from wet processing is known as parchment coffee. The cup quality of parchment coffee will be superior compared to cherry coffee. In India, most arabica coffee is processed by the wet method, while most robusta is processed by the dry method (Anonymous, 2014).

Among various factors, post-harvest processing plays a major role in preserving the innate quality of the coffee. Drying is the most important postharvest operation from the energy consumption point of view and the preservation of the innate quality of the coffee cultivar being handled for processing. Both over-drying and under-drying lead to the formation of defective coffee beans with poor cup quality. Under-dried ( $>12 \%$ moisture content) coffee turns mouldy (fungal contamination) and get bleached during storage of coffee bean. At the same time, over-drying ( $<8 \%$ moisture content) of coffee samples results in woody off-taste in the cup (Menon, 2001).

Much of world coffees are sun-dried using solar energy, though sun drying is a labour-intensive operation. However, in countries like Brazil and Colombia, a major portion of coffee is dried using a mechanical dryer. In sun drying, the beans are heated by direct exposure to the sun by spreading them on drying yards, while in mechanical drying, the coffee mass is exposed to hot air, which absorbs the moisture. In India, some of the coffee estates are equipped with mechanical dryers for drying coffee.

A survey was conducted to assess the performance of mechanical driers (Fig. 1.) installed in 17 estates of coffee growing areas of Chikkamagaluru and Hassan districts in Karnataka state during 2017-18. Information on the performance of the mechanical dryer was collected using a structured questionnaire.

It was observed that most of the dryers in estates are used during the peak harvest period (inclement weather conditions during harvest). The drying temperature varied from $40^{\circ} \mathrm{C}$ to $60^{\circ} \mathrm{C}$. The temperature of the hot air in the drying chamber/ drum was more than the recommended temperature limits to reduce the drying period and, in turn, to reduce the drying cost. Though coffee dryers have been in use for over a few decades, published reports on mechanical drying are mostly relating to drying kinetics (Varadharaju et al., 2001; Izquierdo et al., 2013; Valdiney et al., 2016; Hameed et al., 2018), biochemical (Farah et al., 2006) and organoleptic quality of coffee (Brando, 2004; Farah et al., 2006; Coradi et al., 2007; Taveira et al., 2015; Alves et al., 2017; Hameed et al., 2018; Mesfin and Won, 2020). Reports on the energy requirement of commercially employed mechanical coffee dryer and the economics of drying by various coffee drying systems are limited (Martin et al., 2011). Given the lack of information on these aspects of coffee drying, a study was undertaken to generate information on

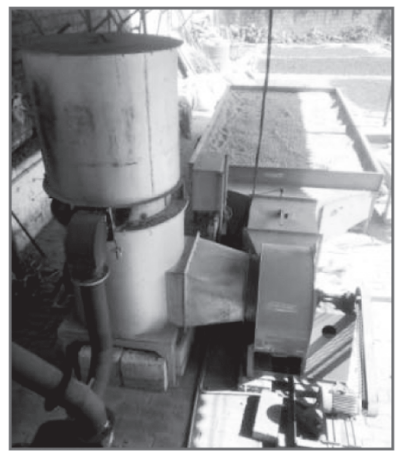

Static dryer

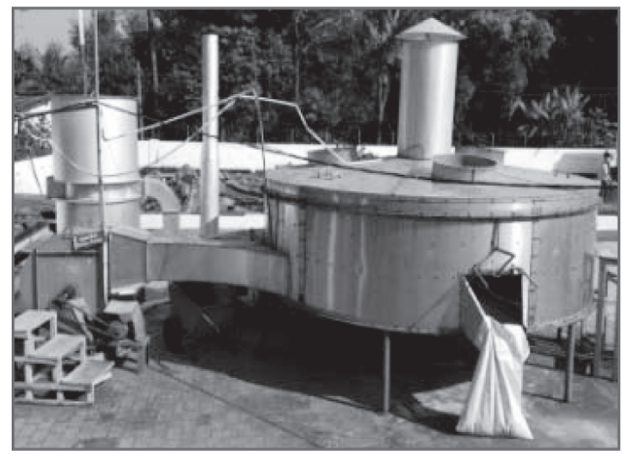

Static dryer with raker

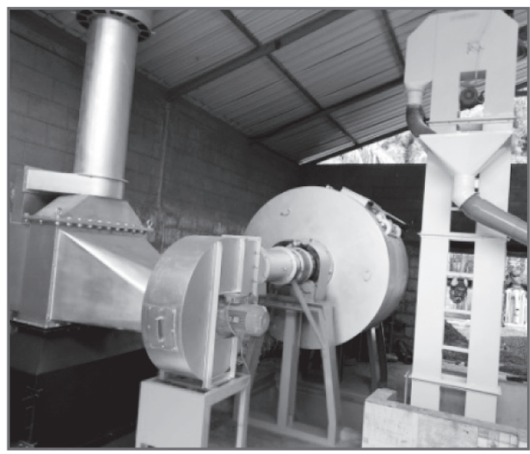

Rotary dryer

Fig. 1. Different types of mechanical dryers employed in Indian coffee estates 
energy requirements of commercially employed mechanical coffee dryer and economics of various coffee drying systems, as well as to gain further insights on drying period and cup quality of robusta coffee samples dried in a rotary mechanical dryer.

\section{Materials and methods}

The work was carried out at Central Coffee Research Institutefarm located at 823-914 $\mathrm{m}$ above MSL with latitude: $13^{\circ} 22^{\prime} \mathrm{N}$ and longitude: $75^{\circ} 28^{\prime} \mathrm{E}$. Coffee drying trials were carried out during the peak harvest season of robusta coffee during February to March 2019-2020.

\section{Coffee harvesting and dry processing}

The fully matured and ripe robusta (Coffea canephora Pieree ex Froehner) coffee fruits were harvested manually from the Central Coffee Research Institute farm. In dry processing, the harvested fresh cherries were pre-dried for two days under the sun to remove the free moisture by spreading them on a clean cemented drying surface and then loaded into a rotary mechanical dryer (Fig. 2) for further drying.

In case of wet processing, the wet parchment coffee samples obtained after complete removal of mucilage were pre-dried for one day under the sun to remove the free moisture and then loaded into a rotary mechanical dryer for further drying. The coffee samples were dried at different temperature regimes $\left(40^{\circ} \mathrm{C} / 50^{\circ} \mathrm{C} / 60^{\circ} \mathrm{C}\right)$ in a rotary mechanical dryer until the coffee samples attain the safe moisture levels (11-12\%) for the safe storage of coffee samples. Parallelly, wet parchment or fresh cherries from the same harvested lot was sun-dried (as a control treatment). During sun drying, the drying thicknesses of coffee samples were maintained at $4 \mathrm{~cm}$ for wet parchment coffee to prevent cracking of parchment skin and $8 \mathrm{~cm}$ for cherry coffee. Coffee samples were turned at regular intervals and dried until the coffee samples attain the prescribed moisture levels for the safe storage of coffee samples. The ambient temperature during sun drying ranged from $26.5^{\circ} \mathrm{C}$ to $32^{\circ} \mathrm{C}$. Coffee samples from rotary mechanical dryer and control coffee lots (sun drying) were sampled at the periodical interval, and moisture content was determined by the International Organization Standardization (ISO) 6673 standard method (1983).

\section{Energy utilization}

The energy consumption in mechanical drying of parchment or cherry coffee is expressed in an equivalent energy unit per batch of drying. The

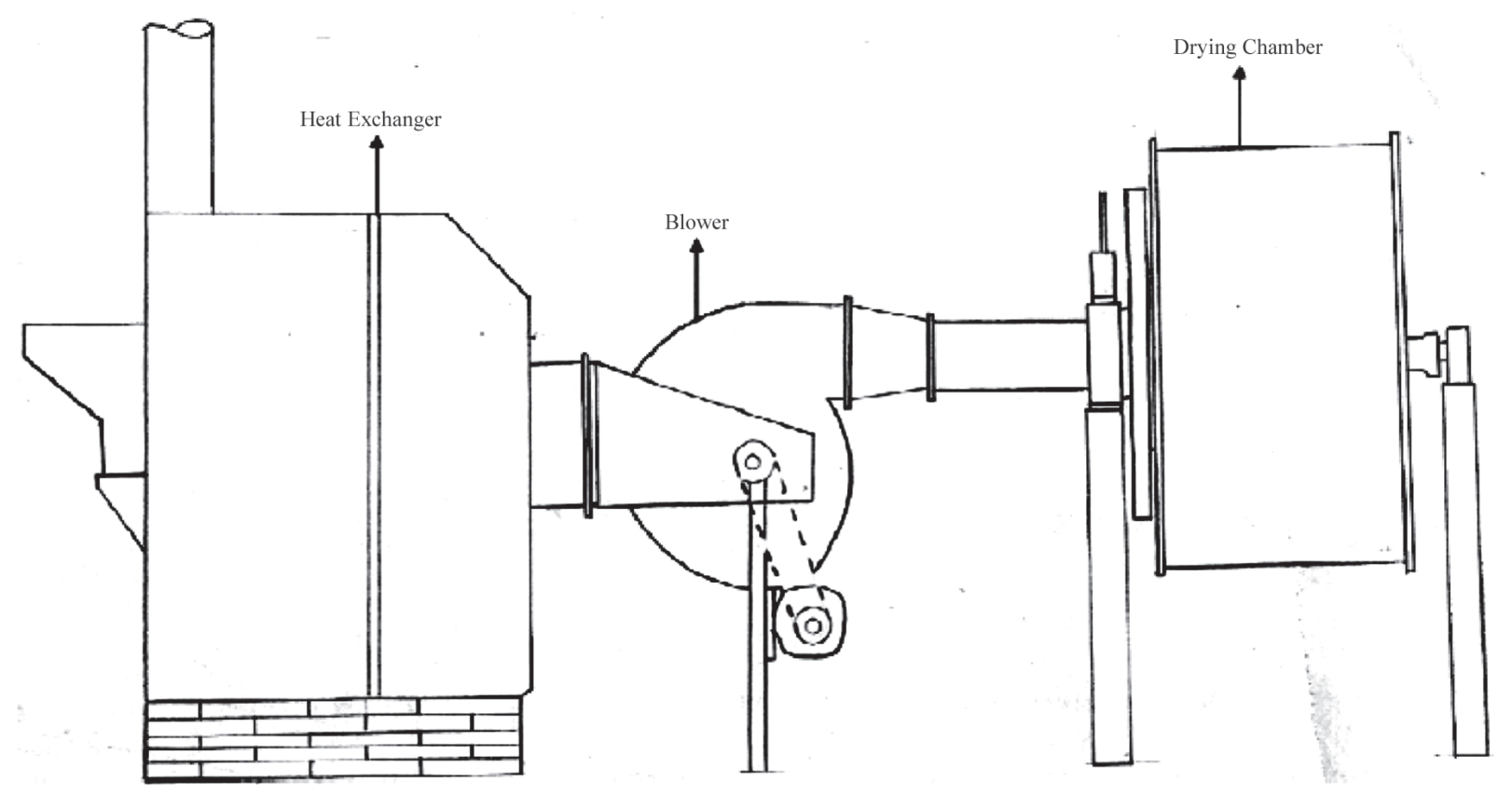

Fig. 2. Schematic diagram of mechanical rotary dryer used in the present study 
energy input expressed in terms of electrical, thermal and human energy. The energy components are calculated based on one tonne of cherry/ parchment coffee, and energy component from each source was estimated using the following procedure (Jekayinfa and Bamgboye, 2006):

\section{Electrical energy}

The rated horsepower of each motor was multiplied by the corresponding hours of operation and summed to find the electrical energy usage by equipment. A motor efficiency of 80 per cent was assumed to compute the electrical inputs.

Where,

$$
\mathrm{E}_{\mathrm{p}}=\mathrm{sPt}(1)
$$

$\mathrm{E}_{\mathrm{p}}$ electrical energy consumed, $\mathrm{kWh}$

$\mathrm{P}$ rated horsepower of motor, $\mathrm{kW}$

t hours of operation, $h$

s power factor (assumed to be 0.8 )

\section{Thermal energy}

The total quantity of energy consumed from firewood was converted to a common energy unit (J) by multiplying the quantity of fuel consumed by the corresponding calorific value (lower heating value) of the fuel used.

$$
\mathrm{E}_{\mathrm{F}}=\mathrm{C}_{\mathrm{f}} \mathrm{W}
$$

Where,

$\mathrm{E}_{\mathrm{F}}$ thermal energy consumed, $\mathrm{J} \mathrm{C}_{\mathrm{f}}$ calorific value of the fuel used, $\mathrm{J} \mathrm{kg}^{-1}$

W quantity of fuel used, $\mathrm{kg}$

\section{Human energy}

To determine the human energy input for a given operation, the time spent by the worker on each operation was recorded. This included the intermittent resting periods. For any unit operation, the manual energy expenditure, $\mathrm{E}_{\mathrm{m}}$, was determined by:

Where,

$$
\mathrm{E}_{\mathrm{m}}=0.075 \mathrm{NT}_{\mathrm{a}}(\mathrm{kWh})
$$

0.075 the average power of normal human labour in $\mathrm{kW}$

$\mathrm{N}$ number of persons involved in an operation

$\mathrm{T}_{\mathrm{a}}$ useful time spent to accomplish a given task (operation) in an hour
Before the commencement of the experiments, a known quantity of firewood was weighed. The initial reading of the electric power reading meter was recorded. After completing the drying of one tonne of coffee, the quantity of the firewood left, and the final reading of the electric meter were taken. The differences in these readings represented the quantity of firewood used (in $\mathrm{kg}$ ) and the electric power consumed (in $\mathrm{kWh}$ ), respectively. The number of persons involved was noted. Based on these values, the cost of drying for one tonne of cherry and parchment coffee was calculated.

\section{Sensory analysis}

Sensory analysis was performed with a cup test using the UCDA method (2010) at Coffee Quality Division, Coffee Board, Bangalore by the experts. Parameters of cup test were fragrance/aroma, flavour, aftertaste, saltiness/acidity, bitterness/ sweetness, mouth feel/body, balance, overall, uniform cup and clean cup.

\section{Results and discussion}

The total drying period (pre-drying and mechanical drying) of robusta cherry was found to be 48,40 and 32 hours at $40^{\circ} \mathrm{C}, 50^{\circ} \mathrm{C}$ and $60^{\circ} \mathrm{C}$, respectively, over 88 hours by sun drying. Similarly, robusta parchment recorded 24, 16 and 16 hours at $40^{\circ} \mathrm{C}, 50^{\circ} \mathrm{C}$ and $60^{\circ} \mathrm{C}$, respectively, over 48 hours by sun-drying, as shown in Figure 3. As drying temperatures increased, the moisture percentage and drying time decreased. Moisture percentage decreased faster at a higher temperature than at a low temperature. At $40^{\circ} \mathrm{C}$, the decrease in moisture percentage was relatively slow.

Accordingly, the total energy utilized and the operation cost for drying robusta cherry and parchment by using a rotary dryer compared with sun drying is illustrated in Tables 1 and 2, respectively.

The results indicated that the energy required was found to be $2.7 \mathrm{MJ}$ and $484 \mathrm{MJ}, 279$ and 199 MJ for sun drying and rotary dryer at 40,50 , and $60^{\circ} \mathrm{C}$, respectively, for drying cherry. Similarly, the sun drying and rotary dryer at 40,50 , and $60^{\circ} \mathrm{C}$ recorded 1.3 MJ and $261 \mathrm{MJ}, 134$ and $135 \mathrm{MJ}$ for drying parchment. When total energy was separated into different forms of energy, it was observed that 


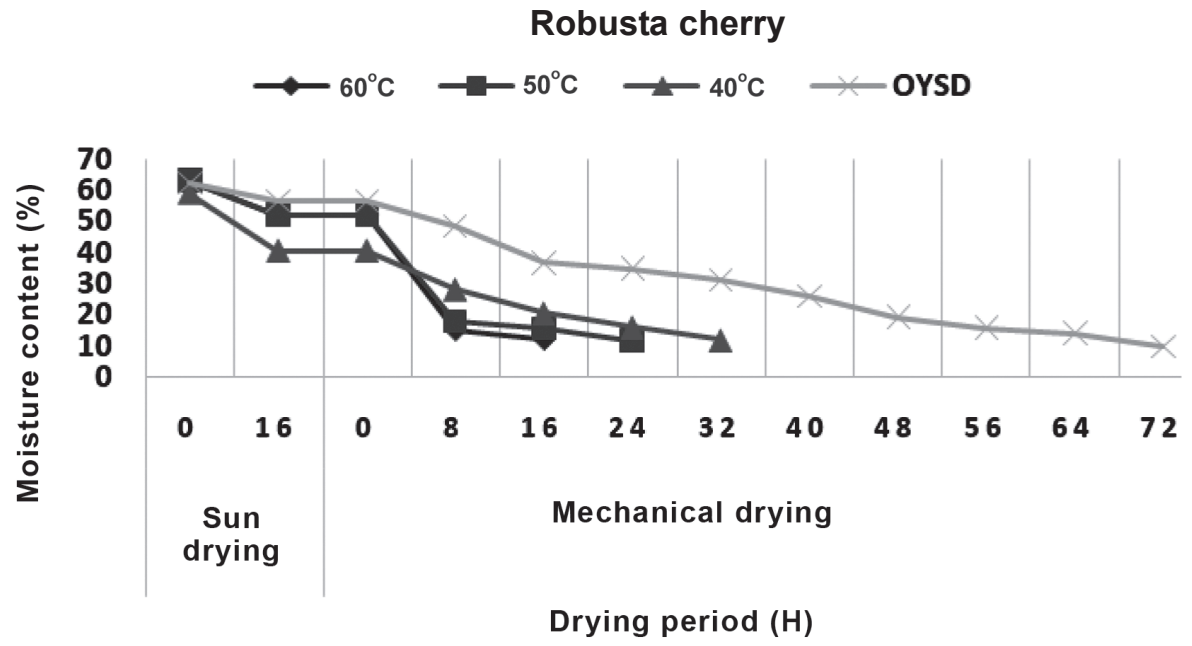

(A)

Robusta parchment

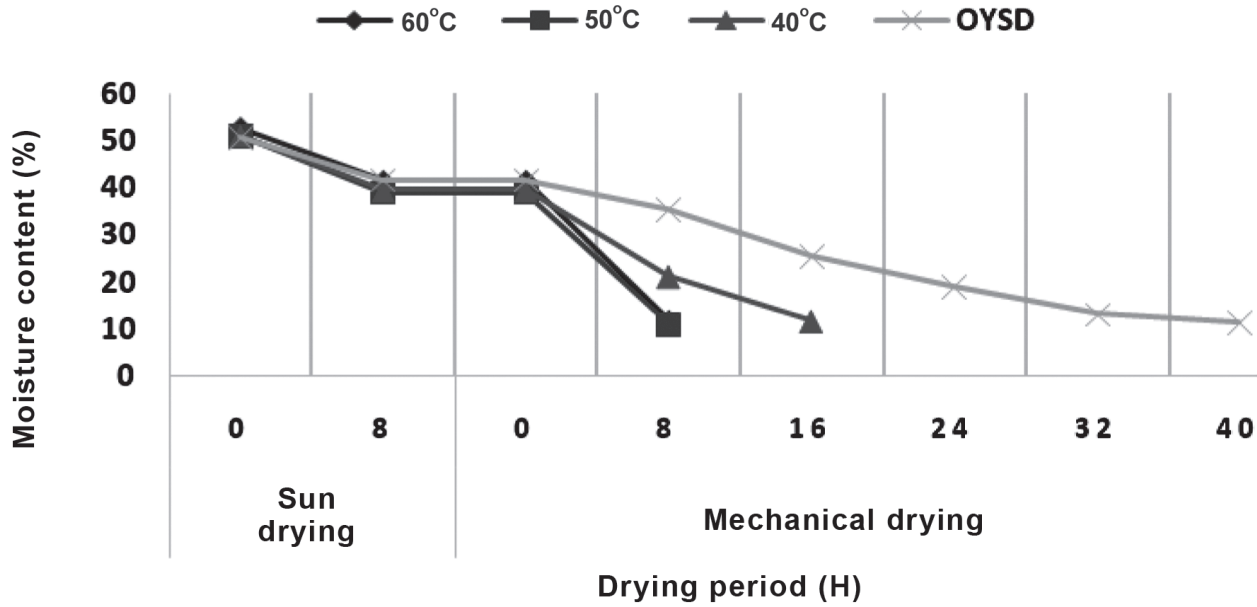

(B)

Fig 3. Effect of drying temperature on drying period of robusta cherry (A) and parchment (B)

Table 1. The total energy required for drying 1 tonne of cherry and wet parchment

\begin{tabular}{|c|c|c|c|c|c|c|c|c|}
\hline \multirow{3}{*}{ Temperature $\left({ }^{\circ} \mathrm{C}\right)$} & \multicolumn{8}{|c|}{ Energy requirement (MJ T $\left.{ }^{-1}\right)$} \\
\hline & \multicolumn{4}{|c|}{ Robusta cherry } & \multicolumn{4}{|c|}{ Robusta parchment } \\
\hline & Electrical & Thermal & Human & Total & Electrical & Thermal & Human & Total \\
\hline $60^{\circ} \mathrm{C}$ & 192.78 & 5.06 & 1.08 & 198.92 & 129.42 & 5.06 & 0.54 & 135.02 \\
\hline $50^{\circ} \mathrm{C}$ & 271.98 & 5.94 & 1.08 & 279.00 & 129.42 & 4.07 & 0.54 & 134.03 \\
\hline $40^{\circ} \mathrm{C}$ & 477.90 & 5.06 & 1.62 & 484.58 & 256.14 & 3.96 & 0.81 & 260.91 \\
\hline Sun-dried & - & - & 2.70 & 2.70 & - & - & 1.35 & 1.35 \\
\hline
\end{tabular}


Table 2. The total drying cost required for drying 1 tonne of cherry and wet parchment

\begin{tabular}{|c|c|c|c|c|c|c|c|c|}
\hline \multirow[t]{3}{*}{ Temperature $\left({ }^{\circ} \mathrm{C}\right)$} & \multicolumn{8}{|c|}{ Cost of drying ( $₹$ per tonne) } \\
\hline & \multicolumn{4}{|c|}{ Robusta cherry } & \multicolumn{4}{|c|}{ Robusta parchment } \\
\hline & Electrical & Thermal & Human & Total & Electrical & Thermal & Human & Total \\
\hline $60^{\circ} \mathrm{C}$ & 1966 & 575 & 1296 & 3837 & 1320 & 575 & 648 & 2543 \\
\hline $50^{\circ} \mathrm{C}$ & 2774 & 675 & 1296 & 4745 & 1320 & 463 & 648 & 2431 \\
\hline $40^{\circ} \mathrm{C}$ & 4875 & 575 & 1944 & 7394 & 2613 & 450 & 972 & 4035 \\
\hline Sun-dried & - & - & 3240 & 3240 & - & - & 1620 & 1620 \\
\hline
\end{tabular}

human energy requirement was highest with sun drying in both cherry $(2.7 \mathrm{MJ})$ and parchment $(1.3 \mathrm{MJ})$ drying, when compared to mechanical drying by rotary dryer for cherry (1.08-1.62 MJ) and parchment (0.54-0.81 MJ). The cost of drying cherry and parchment coffee with different types of drying indicates that mechanical drying considerably increases the cost when compared to sun drying (Table 2).

\section{Sensory analysis}

The cup quality rating of robusta coffee dried by different drying methods revealed that sun-dried robusta parchment coffee scored the highest cup rating (79.5 points out of 100 ), followed by 78.5 , 62 and 50.3 points for those coffees dried at $40^{\circ} \mathrm{C}$, $50^{\circ} \mathrm{C}$ and $60^{\circ} \mathrm{C}$, respectively in a mechanical dryer.

Regarding cherry coffee, sun-dried robusta cherry coffee scored 62.5 points. In contrast, the robusta cherry dried at $40^{\circ} \mathrm{C}$ in mechanical dryer scored the highest cup rating of 70.3 , followed by
56.8 and 49.3 points for the coffees dried at $50^{\circ} \mathrm{C}$ and $60^{\circ} \mathrm{C}$, respectively (Table 3 ). The higher drying rates caused by high temperatures deteriorate coffee quality due to damage to cell membranes (Marques et al., 2008; Borem et al., 2008b). Borem et al. (2008a) verified, through ultrastructural scanning electron microscopy, that natural and pulped caffeine endosperm, during drying at $40^{\circ} \mathrm{C}$ and in the yard, maintained the integrity of the cell membranes and that these membranes were damaged only between moisture contents of 30 per cent and 20 per cent (w.b.), when natural and pulped coffee was dried at a temperature of $60^{\circ} \mathrm{C}$.

\section{Conclusion}

These results indicated a considerable reduction of drying time when coffees are dried in a mechanical dryer $(50 \%$ to $66.6 \%$ and $45 \%$ to $63 \%$ reduction of drying time for parchment and cherry coffees, respectively). Further, the cup quality rating of robusta coffee dried at $40^{\circ} \mathrm{C}$ in a mechanical dryer

Table 3. Influence of drying temperature on cup quality of coffee

\begin{tabular}{|c|c|c|c|c|c|c|c|c|}
\hline \multirow[t]{2}{*}{ Characteristic } & \multicolumn{4}{|c|}{ Robusta parchment } & \multicolumn{4}{|c|}{ Robusta cherry } \\
\hline & $40^{\circ} \mathrm{C}$ & $50^{\circ} \mathrm{C}$ & $60^{\circ} \mathrm{C}$ & Sun drying & $\overline{40^{\circ} \mathrm{C}}$ & $50^{\circ} \mathrm{C}$ & $60^{\circ} \mathrm{C}$ & Sun drying \\
\hline Fragrance/aroma & 7.3 & 6.5 & 5.8 & 7.5 & 6.5 & 6.3 & 6.5 & 6.5 \\
\hline Flavour & 7.0 & 6.0 & 2.0 & 7.5 & 6.0 & 5.5 & 5.8 & 5.5 \\
\hline After taste & 7.0 & 5.0 & 4.0 & 7.5 & 6.3 & 4.5 & 5.0 & 5.0 \\
\hline Salt/acid & 7.5 & 5.5 & 4.0 & 7.3 & 6.3 & 5.5 & 5.0 & 5.5 \\
\hline Bitter/sweet & 7.5 & 4.5 & 4.5 & 7.3 & 6.0 & 5.0 & 4.0 & 5.0 \\
\hline Mouth feel & 7.5 & 4.5 & 3.0 & 7.5 & 6.3 & 4.5 & 5.0 & 5.0 \\
\hline Balance & 7.3 & 5.0 & 3.5 & 7.5 & 6.5 & 5.0 & 5.0 & 5.0 \\
\hline Uniformity & 10.0 & 10.0 & 10.0 & 10.0 & 10.0 & 10.0 & 6.0 & 10.0 \\
\hline Clean cup & 10.0 & 10.0 & 10.0 & 10.0 & 10.0 & 8.0 & 6.0 & 10.0 \\
\hline Overall & 7.5 & 5.0 & 3.5 & 7.5 & 6.5 & 4.5 & 5.0 & 5.0 \\
\hline Defects (Deduction) & 0.0 & 0.0 & 0.0 & 0.0 & 0.0 & 2.0 & 4.0 & 0.0 \\
\hline Total & 78.5 & 62.0 & 50.3 & 79.5 & 70.3 & 56.8 & 49.3 & 62.5 \\
\hline
\end{tabular}


scored equal or higher quality points than sun-dried coffees, indicating that the drying temperature should not exceed more than $40^{\circ} \mathrm{C}$ for preserving the innate quality of robusta coffee. Overall, mechanical drying is more advantageous to sun drying in-terms of drying hours (indirectly reduces dependency on manpower) and preservation of innate quality of the coffee.

\section{Acknowledgement}

The authors would like to thank Dr. N. Suryaprakash Rao, Joint Director (Research), Central Coffee Research Institute, CRS Post, Chikkamagalur district, Karnataka, India, for his kind guidance and support for this work. We also thank the Coffee Quality Division, Coffee Board, Bangalore, for assessing the cup quality of coffee samples.

\section{REFERENCES}

Alves, G.E., Borem, F.M., Isquierdo, E.P., Siqueira, V.C., Cirillo, M.A. and Pinto, A.C.F. 2017. Physiological and sensorial quality of Arabica coffee subjected to different temperatures and drying airflows. Acta Scientiarum Agronomy 39(2): 225-233.

Anonymous 2014. Coffee guide: A manual of coffee cultivation published by Central Coffee Research Institute, Coffee Research Station, Government of India, Chikkamagalur district, Karnataka, India.

Borem, F. M., Marques, E. R., and Alves, E. 2008 a. Ultrastructural analysis of drying damage in parchment Arabica coffee endosperm cells. Biosystems Engineering 99(1): 62-66.

Borem, F. M., Coradi, P. C., Saath, R., and Oliveira, J. A. 2008b. Quality of natural and pulped coffee after drying on a terrace and with high temperatures. Science and Agrotechnology 32(5): 1609-1615.

Brando, C. 2004. Harvesting and green coffee processing. In: Coffee: Growing, Processing, Sustainable Production, J.N. Wintgens, Weinheim: Wiley -VCH Verlag $\mathrm{GmbH}$ and $\mathrm{Co}, \mathrm{KGaA}$, p. 604-715.

Coradi, P.C., Borem, F.M., Saath, R. and Marques, E.R. 2007. Effect of drying and storage on the quality of natural and washed coffee. Coffee Science 2(1):38-47.

Database on Coffee 2020. Coffee Board of India.https:// www.indiacoffee.org/database-coffee.html viewed on 3rd July 2020.
Farah, A., Monteiro, M. C., Calado, V., Franca, A. S. and Trugo, L. C. 2006. Correlation between cup quality and chemical attributes of Brazilian coffee. Food Chemistry 98(2): 373-380.

Hameed, A., Hussain, S.A., Ijaz, M.U., Ullah, S., Pasha, I. and Suleria, H.A.R. 2018. Farm to consumer: Factors affecting the organoleptic characteristics of coffee. II: Comprehensive Reviews in Food Science and Food Safety 17(5): 1184-1237.

International Organization Standardization, ISO 6673 (1983). Green coffee - Determination of loss in mass at $105^{\circ} \mathrm{C}$. Geneva, 17p.

Isquierdo, E. P., Borem, F. M., Andrade, E. T., Correa, J. L. G., Oliveira, P. D. and Alves, G. E. 2013. Drying kinetics and quality of natural coffee. Transactions of $A S A B E$ 56(3): 1003-1010.

Jekayinfa, S.O. and Bamgboye, A.I. 2006. Estimating energy requirement in cashew (Anacardium occidentale L.) nut processing operations. Energy 31: 1305-1320.

Marques, E. R., Borem, F. M., Pereira, R. G. F. A., and Biaggioni, M. A. M. 2008. Effectiveness of the grease acidity test in evaluating the quality of Arabica coffee (Coffea arabica L.) submitted to different drying periods and temperatures. Science and Agrotechnology 32(5): 1557-1562.

Martin, S., Silva, J.N.D., Zanatta, F.L., Galvarro, S.F.S. and Volk, M.B.D.S. 2011. Evaluation of coffee drying costs: pre-drying on concrete terrace and complementary drying in co-current and counter-current flow dryer. Coffee Science 6(3): 217-225

Menon, S.N. 2001. Quality, value, perceived price. Tea and Coffee Asia 34: 82-88

Mesfin, H. and Won H. K.2020. The Harvest and Post-Harvest Management Practices' Impact on Coffee Quality. DOI: ttp://dx.doi.org/10.5772/intechopen.89224.

Taveira, J.H.D.S., Borem, F.M., Da Rosa, S.D.V.F., Oliveira, P.D., Giomo, G.S., Isquierdo, E.P. and Fortunato, V.A.2015. Post-harvest effects on beverage quality and physiological performance of coffee beans. African Journal of Agricultural Research 10(12): 1457-1466.

Valdiney, C. S., Borem F.M., Alves, G.E., Isquierdo, E.P., Pinto, A.C.F., Ribeiro, D.E. and Ribeiro, F.C.2016. Drying kinetics of processed natural coffee with high moisture content. Coffee Science 12(3): 400-409.

Varadharaju, N., Karunanidhi, C. and Kailappan, R.2001. Coffee cherry drying: a two-layer model. Drying Technology 19: 709-715. 